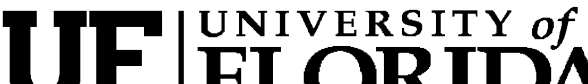 FLORIDA \\ IFAS Extension
}

\section{The Common Roles of Fathers: The Five Ps ${ }^{1}$}

Kate Fogarty and Garret D. Evans ${ }^{2}$

\section{Overview}

Fathers play many roles in parenting their children. Some are involved in every facet of their child's life, while others concentrate on one or two aspects of raising their child. In the United States today, fathers typically take on even more responsibility for raising their children than in the generations that preceded them.

Studies of parenting behaviors suggest that fathers tend to concentrate their efforts on a handful of basic parenting responsibilities. Fathers' efforts can be labeled according to the "Five Ps":

- Participator / Problem-solver

- Playmate

- Principled guide

- Provider

- Preparer

Before explaining these activities, we need to say that the "Five Ps" are not things fathers do that mothers cannot. Mothers often perform some or all of these roles themselves, quite capably. Rather, they represent activities fathers use to define themselves, because they see them as important for raising their child.

\section{Participator / Problem-solver}

Fathers can sometimes overlook the importance of being engaged in their child's life. Being there for a child is more than physical presence; it involves helping children to meet their social, emotional, and psychological needs. A father who is a participator is someone who has direct interactions with their child (such as caretaking, or leisure and play). He is also someone who is available to their child, and takes responsibility for making arrangements for their child's needs to be met (Pleck \& Masciadrelli, 2004). Less "visible" is the responsible father who is involved in the indirect care for the child-for example, activities done for, but not with, the child, such as arranging transportation and appointments (Pleck \& Masciadrelli, 2004).

Fathers talk about the importance of helping their children solve many of the critical problems of growing up. These could be challenges such as deciding: what to do for a living, whether to go to

1. This document is FCS2140, one of a series of the Department of Family, Youth, and Community Sciences, Florida Cooperative Extension Service, Institute of Food and Agricultural Sciences, University of Florida. Publication: December 1999. Revised: November 2009. Please visit the EDIS Web site at http://edis.ifas.ufl.edu.

2. Kate Fogarty, Ph.D., assistant professor, Youth Development, and Garret D. Evans, Psy.D., former assistant professor in Clinical Psychology, both of the Department of Family, Youth and Community Sciences, Florida Cooperative Extension Service, Institute of Food and Agricultural Sciences, University of Florida, Gainesville FL 32611.

The Institute of Food and Agricultural Sciences (IFAS) is an Equal Opportunity Institution authorized to provide research, educational information and other services only to individuals and institutions that function with non-discrimination with respect to race, creed, color, religion, age, disability, sex, sexual orientation, marital status, national origin, political opinions or affiliations. U.S. Department of Agriculture, Cooperative Extension Service, University of Florida, IFAS, Florida A. \& M. University Cooperative Extension Program, and Boards of County Commissioners Cooperating. Millie Ferrer-Chancy, Interim Dean 
college, whether to buy a car; or, it could be everyday tasks such as homework, fixing a bike, or hanging a swing from a tree.

As participator fathers model effective problem-solving skills for their child (Doucette, 2006). Fathers have an opportunity to show their child how to make and act on decisions, as well as how to navigate the experience of the consequences of their actions and decisions. This process fosters a child's responsibility, independence, and self-reliance. If a child is raised lacking role models for effective problem-solving, the child often adopts poor strategies that lead him or her to act helpless. Children and adults with deficient problem-solving skills often become needy and dependent on others to "make things right" in their life. On the positive side, fathers who model healthy problem-solving in relationships have children who are less aggressive and more popular with their peers and teachers.

While a father often plays a critical role in his child's life by setting an example of problem-solving, he may sometimes get involved in solving problems when it's nearly too late. In some family situations, a father may only get involved when a child's emotional and behavioral problems have become serious, for example, when a teacher requests to conference with a parent over a child's problem (Badalament, 2008). Reserving father's help for only the "big" problems is unhealthy. Fathers need to be involved in all phases of their child's

problem-solving, from serving as an example to that of a guide who offers possible solutions.

\section{Playmate}

Fathers can be great "jungle gyms." Research shows that fathers spend more time, in general, with their children in high-energy, physical play than do mothers. In addition, fathers tend to engage in more roughhousing and stimulating play than mothers. This prompts children to form expectations that the majority of their physical play activities will occur with fathers. For example, a daughter hangs on her father's arm and wants to swing as soon as he comes through the front door on his way home from work. This type of play can be very important in a child's life. Physical play not only builds muscles and coordination, but can often be used to teach rules that govern behavior (for example, taking turns, standing in line, playing physically without injuring someone, etc.). As a playmate, a father can encourage his child's sense of autonomy and independence, which is a major milestone of social and emotional growth.

In addition, play is often termed a "window to the child's world." This means that play can often be used to find out about a child's thoughts, feelings, hopes, and dreams. During play, a father can learn a lot about their child, if they listen closely. This information can be used to start an on-going conversation with his child about things that are important to them. In fact, it's important that a father uses this time to talk with his child and to build an emotional bond. Too often, a father misses this opportunity by simply playing and substituting physical contact for verbal interaction.

\section{Principled Guide}

The cliché, "Wait 'til your father gets home!" has long been used as a threat to children to discourage misbehavior. However, the statement should not be used to describe a father's responsibility, especially because punishment reflects a negative assertion of adult power. Punishment emphasizes to a child what not to do, rather than how parents would like a child to act. Also, punishment may be the result of a parent's emotional reaction to a child's behavior. As a result, a child may feel shamed and humiliated which undermines trust in the parent-child relationship. Also, the child's sense of autonomy and initiative may be inhibited, especially when a child's 'unacceptable' behavior is well-meaning. Guidance, on the other hand teaches socially desirable behavior, helps children to learn the difference between right and wrong, and enables children to experience and understand the consequences of their own behavior. Fathers who serve as guides for their children not only maintain their authority, but use it more effectively. Guidance is a collaborative effort. Between a father and child, guidance involves an ongoing process of healthy communication (e.g., listening first, then discussion and instruction). Likewise, agreement between fathers and mothers on guidance strategies is important, particularly when it comes to learning consequences of unacceptable behavior. If one parent 
allows the child to experience the consequences of his or her poor decision, and the other 'rescues' the child from the consequences, problems are likely to occur. On the other hand, when parents agree on guidance strategies for their children, including discipline, the child is more likely to learn from the consequences of their poor decisions. Guidance must be a balance between correcting unacceptable behavior and encouraging acceptable behavior.

\section{Provider}

In the last few decades, mothers have entered the work force in unprecedented numbers. Yet, men continue to be identified as the primary "breadwinner" for the family (Wall \& Arnold, 2007). This is not always the case, as some fathers have chosen to be the primary caregivers for their children. For example, fathers may choose to care for their children while working out of the home or continuing their education. Nonetheless, American society still values the ability of the father to provide tangible resources (i.e., food, money, shelter, material possessions) for their children. Policies enforcing non-resident fathers to pay child support reflect such values.

However, fathers are more than the provider of material things (e.g., income and resources) for children and families, a father's provider role can also be defined in terms of care of the child. All too often, fathers have been led to believe that providing income and material support is all there is, their only way for caring for their family. This is unfortunate, because it discourages fathers from participating in all of the other parenting activities that are even more fulfilling, such as guidance, play, school activities, and connecting with community resources to promote child development.

As fathers identify themselves more as caretakers, they are more likely to connect with other parents and child care providers in the community. In turn, fathers are potentially powerful advocates for child welfare (see Andrea Doucet's 2006 book, Do Men Mother?). This reflects a recent social movement for fathers which changes how they view themselves and their fathering roles in both the family and community.

\section{Preparer}

Fathers are often involved in preparing their children for life's challenges. They may talk with their child about family values and morals, and model appropriate behavior (Pleck \& Masciadrelli, 2004: Nicholson, Howard, \& Borkowski, 2008). Or, fathers may advise their teenagers about educational and employment goals, as well as give advice (when asked for) about peer and romantic relationships. They may guide their child about how to behave in school and work to ensure their child's success in those areas. They may discuss the importance of being truthful, of giving an "honest day's work for an honest day's pay," or showing their affection to a spouse or partner.

Often, fathers see their relationship with their child blossom as the child grows into adolescence and adulthood. Fathers experience a transition in their role as a child ages; for example, fathers are "nurturers" of babies but "teachers" of toddlers. Some fathers see adolescence as the time to get involved in preparing their children for the "real world." In truth, fathers don't need to wait until their children approach adulthood in order to teach them important life lessons. Fathers can provide moral guidance and practical lessons all the way through their child's life. And, to learn more about the father-child relationship through the lifespan, especially fathers and sons, read Michael Diamond's 2007 book, My Father Before Me: How Fathers and Sons Influence Each Other Throughout Their Lives.

Involvement helps build an ongoing partnership between father and child. Perhaps more importantly, though, through their influence on many areas of children's lives, fathers teach their children how to be parents. In fact, studies found that fathers strongly influenced the parenting styles of children (Nicholson, et al., 2008). Still other studies show that men growing up with fathers who were poor role models compensated for this by being especially involved in their children's lives (Pleck \& Masciadrelli, 2004). 


\section{The Five Ps: Is That All There Is?}

While the "The Five Ps" can be a simple guide for categorizing ways that fathers are commonly involved in their child's life, there's no need to restrict your experiences as a father to these 5 categories. Yet the activities fathers are involved in today tend to fit, more or less, into one of the five P's. For example, if a father acts as a primary caretaker for his children, the activities he engages in will fit into all 5 categories. Moreover, these roles don't just apply to biological fathers, but stepfathers too. Men are more likely today to spend some time in their lives as stepfathers, so their influence on children and families cannot be overlooked. The benefits of this expanded involvement are clear for both the child and the father (see: The Hidden Benefits of Being an Involved Father FCS2137).

So, no-that's not all there is: fathers who look for a variety of ways to be involved in their child's life contribute to a healthier family and a healthier future for their child.

\section{References}

Badalament, J. (2008). Engaging modern dads in schools. Independent School, 67. [Online] Retreived November 10, 2008 from http://www.pressomatic.com/tridentacademy/upload/ msilgals//Why\%20Schools\%20Need\%20to.pdf.

Diamond, M.J. (2007). My Father Before Me: How Fathers and Sons Influence Each Other Throughout Their Lives. New York: W. W. Norton \& Company

Doucet, A. (2006). Do Men Mother? Fathering, Care, and Domestic Responsibility. Toronto: University of Toronto Press.

Gordon, A., \& Browne, K.W. (1996). Guiding Young Children in a Diverse Society. Boston, MA: Allyn \& Bacon.

Jain, A., Belsky, J. \& Crnic. K. (1996). Beyond fathering behaviors: Types of dads. Journal of Family Psychology, 10, 431-442.
Kazura, K. (2000). Fathers' qualitative and quantitative involvement: An investigation of attachment, play, and social interactions. The Journal of Men's Studies, 91, 41-57.

Marsiglio, W., Amato, P., Day, R.D., \& Lamb, M.E. (2000). Scholarship on fatherhood in the 1990s and beyond. Journal of Marriage \& the Family, 62, 1173-1191.

Marsiglio, W. (1995). Fatherhood: Contemporary

Theory, Research, and Social Policy. Thousand Oaks, CA: Sage.

Nicholson, J.S., Howard, K.S., \& Borkowski, J.G. (2008). Mental models for parenting: correlates of metaparenting among fathers of young children. Fathering: A Journal of Theory, Research, and Practice, 6, 39-61.

Palkovitz, R. (2002). Involved fathering and child development: Advancing our understanding of good fathering. In C.S. Tamis-LeMonda \& N. Cabrera (Eds.), Handbook of Father Involvement: Multidisciplinary Perspectives (pp. 119-140). Mahwah, NJ: Lawrence Erlbaum.

Palkovitz, R., \& Palm, G. (2009). Transitions within fathering. Fathering: A Journal of Theory, Research, and Practice, 7, 3-22.

Parke, R.D., McDowell, D.J., Kim, M., Killian, C., Dennis, J., Flyr, M.L., \& Wild, M.N. (2002). Fathers' contributions to children's peer relationships. In C.S. Tamis-LeMonda \& N. Cabrera (Eds.), Handbook of Father Involvement: Multidisciplinary Perspectives (pp. 141-167). Mahwah, NJ: Lawrence Erlbaum.

Pleck, J.H., \& Masciadrelli, B.P. (2004). Paternal involvement by U.S. residential fathers: Levels, sources and consequences. In M.E. Lamb (Ed.), The Role of the Father in Child Development, 4th Edition (pp. 222-271). Hoboken, NJ: Wiley.

Wall, G., \& Arnold, S. (2007). How involved is involved fathering? An exploration of the contemporary culture of fatherhood. Gender \& Society, 21, 508-527. 